\title{
Daily work and access to health services of female sex workers
}

\author{
Cotidiano de trabalho e acesso aos serviços de saúde de mulheres profissionais do sexo
}

Nayara Santana Brito ${ }^{1}$, Jameson Moreira Belém ${ }^{1}$, Tayenne Maranhão de Oliveira ${ }^{1}$, Grayce Alencar Albuquerque ${ }^{1}$, Glauberto da Silva Quirino ${ }^{1}$

Objective: to understand the daily work and access to health services of female sex workers. Methods: qualitative research using the ethnographic method. Participant observation with record in a field journal, semi-structured interviews, and a form with sociodemographic data were used for the data collection. For data analysis, thematic analysis was associated to ethnography. Results: four thematic categories emerged: insertion in prostitution; family relationships; suffering and illness; and access to health services. Conclusion: the daily life of the women is marked by precarious working conditions and the search for health services to solve specific problems at their own initiative. The work routine in this context places women in situations of clinical and social fragility, exposing them to vulnerabilities in health.

Descriptors: Sex Workers; Health Services Accessibility; Women's Health; Health Promotion; Health Vulnerability.

Objetivo: compreender o cotidiano de trabalho e o acesso aos serviços de saúde de mulheres profissionais do sexo. Métodos: pesquisa qualitativa que utilizou o método etnográfico. Para a coleta de dados, foram utilizadas observação participante com registro em diário de campo, entrevista semiestruturada e formulário com dados sociodemográficos. Para a análise dos dados, associou-se à análise temática dos dados à etnografia. Resultados: emergiram quatro categorias temáticas: inserção na prostituição; relações familiares; sofrimento e adoecimento; e acesso aos serviços de saúde. Conclusão: o cotidiano das mulheres é marcado por condições precárias de trabalho e pela busca por serviços de saúde para resolução de problemas específicos, por iniciativa da mulher. A rotina de trabalho nesse contexto coloca as mulheres em situações de fragilidade clínica e social, expondo-as a vulnerabilidades em saúde.

Descritores: Profissionais do Sexo; Acesso aos Serviços de Saúde; Saúde da Mulher; Promoção da Saúde; Vulnerabilidade em Saúde.

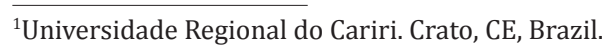




\section{Introduction}

Female prostitution is considered to be the oldest commercial activity of mankind and consists in a paid sexual relationship where the most important bond is not reciprocal affection or desire, but the mediation of sexual pleasures for material goods, in which the woman sells a sexual experience ${ }^{(1)}$.

In Brazil, currently, the category "sex worker" is recognized as informal work by the Ministry of Labor and Employment. However, from the point of view of Brazilian morality, these women continue to be socially marginalized and victims of prejudice and discrimination through social judgment ${ }^{(2-3)}$.

Challenges faced by sex workers lead to specific health demands, often related to sexual and reproductive health, such as unwanted pregnancies, abortions, maternal health problems, and Sexually Transmitted Infections (STIs). There are also risks to physical health; these women are in a situation of vulnerability related to mental health and at increased risk for physical and sexual violence ${ }^{(4-5)}$. Such demands should not only be addressed by one-off actions but should involve the social determinants of health, quality of life, and the need to expand access to health services ${ }^{(3)}$.

Access to health services is a multidimensional concept that results from the interaction of several individual and collective factors, including the absence of sociocultural, organizational, economic, geographic and gender-related barriers to health care, as well as the capacity of health systems to meet the needs of populations at any level of care, providing adequate infrastructure, capacity in terms of human resources and health technologies without causing financial harm $^{(6-7)}$.

In an integrative review of the literature on the health care of sex workers, it was verified that few studies had addressed questions related to this theme in Brazil. And when they were approached, they were mostly related to STIs and their forms of transmission than to the promotion of women's health ${ }^{(8)}$. In this sense, a systematic review pointed out that among the difficulties faced by these women when they sought health services were the fear of judgment by health professionals and other users. Another finding was that despite the increased availability of services, sex workers continued to face individual, social, structural and political barriers to accessing them ${ }^{(5)}$.

In order for health care to take place adequately, there is a clear need to train health professionals to establish a link with these users, requiring an educational approach to the situation experienced, with effective participation of all parties involved, making it possible to promote equity, health empowerment, and healthy behaviors ${ }^{(9)}$. In order to achieve these prerogatives, it is necessary to expand access to health services with quality care, adequate embracement, and troubleshooting ${ }^{(3)}$.

Given this, knowing the daily work of these users and their access to health services is a key element to promote health actions that are appropriate to their real needs.

Thus, the following questions was raised: how is the daily work of female sex workers? How do these women access health services? To answer them, the objective was to understand the daily work and access to health services of female sex workers.

\section{Methods}

Qualitative research using the ethnographic method to interpret the meanings attributed to the experiences lived by sex workers from the perspective of social actors in their cultural context ${ }^{(10)}$. The study was conducted in a city in the countryside of the state of Ceará, Brazil.

The immersion in the field occurred through visits to the prostitution sites of the city from January to June 2015. After the mapping of the space, the Central Market was chosen as locus, where there were old houses selling alcoholic beverages and where sex workers offering their services were observed. Initially, introductory visits were made with the intention of establishing an initial contact with the people 
responsible for the establishments, who were informed about the objectives of the study.

It is noteworthy that the sites covered were not considered brothels or houses of prostitution. The owners claimed that there were rooms that were rented by customers. This is because the maintenance of brothels and the practice of ruffianism are prohibited by the Brazilian Penal Code ${ }^{(11)}$. After the contact, only one establishment authorized the presence of the researchers. Then, data collection was started.

For the recruitment of the participants, the snowball sampling technique was used, in a non-probabilistic manner, using reference chains, where the first interviewees indicated the next ones until the saturation point was met ${ }^{(12)}$. The first interviewee was indicated by the bar owner who played the role of key informant. To participate, it was necessary that the woman had at least 18 years of age, worked with prostitution for at least one year, and had sex work as main source of income. The interviewed women were chosen according to the willingness to answer the questions and the dynamics of the fieldwork. During data collection, 13 women were observed, and eight participated in the interview.

In addition to participant observation with field journaling, data were collected through a form addressing sociodemographic data and through a semi-structured interview. Interviews were audiotaped and performed individually during work breaks, and ranged from 45 minutes to one hour. The questions focused on daily life, exercise of prostitution, and access to health services. The participants were identified by fictitious names chosen by them.

After data collection, the audios were transcribed. The experiences of the women, the scenario, the routine, and the social dynamics were recorded in the field diary, which were inserted analytically into thematic categories and helped to describe the facts of the daily life of these women.

Thematic analysis was applied to analyze the data, using the expressions and excerpts of the women's speeches that were significant as empirical categories $^{(13)}$. Four categories were developed: insertion in prostitution; family relationships; suffering and illness; and access to health services.

The analysis of ethnographic data was done by associating the thematic analysis with the record of observations ${ }^{(14)}$. This phase was carried out in three steps: in the pre-analysis, the interviews were exhaustively read, using the colorimetric method to classify convergent speeches. Then, these lines were organized according to the main themes; in the exploration of material, the answers were organized according to the main themes and divided into categories; in the treatment of the results obtained and interpretation, the organized data were analyzed in an inductive and interpretive way. The thematic categories were presented and the meanings were exemplified by excerpts of the testimonies.

The study complied with national standards for research involving human subjects and was approved by the Research Ethics Committee of the Regional University of Cariri, under Opinion no 328.925 and Certificate of Presentation of Ethical Appreciation $\mathrm{n}^{\mathrm{o}}$ 16688113.1.0000.5055.

\section{Results}

Eight sex workers aged between 24 and 41 years, with a mean of 31.3 years, participated in the study. In relation to schooling, five had completed high school and three had completed elementary school. All declared to be single and five had children.

The respondents reported staying in the facility and said that relatives lived in other cities or districts away from downtown. None of them had fixed monthly income from work, since this varied each month depending on the number of clients, making up approximately one minimum wage $(\mathrm{R} \$ 788.00$ in force at the time). However, five were beneficiaries of social programs of the Federal Government. At the locus of the study, on Mondays and Wednesdays, there was a 
popular fair that attracted people from various neighborhoods and near cities, including cowboys, farmers, traders and consumers.

There were seven bars functioning in old houses. The bar in which the survey took place opened at $7.00 \mathrm{pm}$ and closed around 7.00 am and did not open on Sundays, had a main hall where some tables, chairs were distributed, and there was a curtain through which people could pass only with authorization of the security man. Behind the curtain, there was a counter where alcoholic beverages were sold, and to the left, a corridor leading to the bedrooms. The room had little light, loud music and was located near the open stream that received the sewage of the city.

The main hall of the bar had an entrance gate only. The absence of windows made it difficult for air to circulate. There was therefore a strong smell of cigarette and alcohol. One of the study participants reported that she was not satisfied with the hygiene conditions: I do not like to work here, the rooms are dirty, men are dirty. When I go to work in other cities, we have sheets to change whenever the customer leaves, we have condoms at ease, here it is not like that (Cidinha).

\section{Insertion in prostitution}

This first category refers to the process of insertion of women in prostitution and their material conditions of income and work.

The women had been working with prostitution for six to 16 years, with the onset of activity between 16 and 18 years of age. The reasons that led them to start were linked to economic factors, mediation of close people, and violence. The material conditions of subsistence were decisive for the situation of prostitution: A woman from the nearby town told my mother that she had a job for me, that I could work at her house as a housekeeper. I came and thought it was to clean, cook, but then I realized what the place was, and she started to put me to do sex work; I had to do it to eat, I cried a lot (Juliana). After I was arrested, I couldn't find a job, so the way I found to get some money was this (Kelma).
Women talked about the difficulty of changing jobs and having another source of income in a context of social stigma: People who know always talk, but I have nothing else to do (Gabriela). There in the city where I was born, I worked in a nursery, I really like children, and I wanted to go back to working with children, but I do not have the opportunity anymore. Once people know that we have been prostitutes, it becomes very difficult to get a job (Juliana).

\section{Family relationships}

In this category, the relationship between sex workers and their families is discussed. The parents of the women were aware of their prostitution activities. However, the children were unaware of that fact: $M y$ brother knows, my parents know (Leonora). "God forbids” my daughter know what I do; but my mother knows (Cidinha).

\section{Suffering and illness}

In this category, the main causes of suffering and illness were explored. Concerning feelings about prostitution, these ranged from discomfort to indifference: I don't feel good, but I have no choice (Juliana). I don't feel anything, I'm doing it already for so long (Kelma).

Among the five interviewees who had children, all said that the greatest suffering was knowing that their children would grow up knowing their work. Also, the fact that they have to be away for long periods. The women who still lived with their parents reported that the suffering of their parents of knowing that their daughters were prostitutes was what most distressed them. All of them suffered prejudice, whether on the part of the family or society: It's bad to see our children growing up seeing all this stuff (Emanuela). "God forbids" my daughter know what I do; she is already 11, she's a young girl, I'm afraid she gets revolted if she finds out (Cidinha).

The interviewees stated that they had no health problems, had no history of STIs, and took care of themselves, using condoms, going to the doctor regularly, and using contraceptive methods. However, they 
recognized that the exercise of prostitution increased vulnerability in health and violence: I've never had anything, I just had these things of violence, of fighting... I think you really have to take care of yourself, you have to take care, I take care of myself, I've made those exams that you do at the hospital, you have to do it, we stay here and we don't know what we have (Leonora). I take care of myself to avoid diseases, I use condoms and I go to the doctor, I take contraceptive pills, to avoid pregnancy (Gabriela). I take care of myself, because I don't want to have children anymore, I'm almost 40 (Neidinha).

According to the interviewees, there was a program of health care for sex workers in the city, with delivery of condoms and contraceptives, but it was not possible to guarantee that all women would use this service due to the migratory movement between the cities, which made it impossible for there to be a continuity of care: There in the other city that I work, things are already well organized, the team makes a meeting with the girls at the bar where I work, we have a card, where the team controls our exams, contraceptives, and condoms. The contraceptive I take was chosen after a consultation with the nurse, and on the card says the day I should take it (Cidinha).

\section{Access to Health Services}

Information about access of the interviewees to health services and how they were assisted is presented in this category.

The sex workers showed resistance to seeking health services with a preventive approach. Only one of them reported frequent visits to the basic health unit for consultations and to receive contraceptives and condoms: I'm going to the health unit to get contraceptives and condoms; and if it there is nothing available, I'll buy it. But if I get pregnant, I won't abort (Cidinha). I look for help only when I feel something (Kelma).

On the other hand, the women who sought public services had difficulties in accessing consultations and examinations, opting in some situations for private services.

Most of the women said they made gynecological examinations with regularity, and the last one had been done less than a year ago. None of them reported maltreatment on the part of the professionals who attended them: I go there mainly to get contraceptives and condoms (Gabriela). I've never been mistreated, the only bad thing is the delay, the service takes too long. We have to wait a lot for the service (Emanuela). I've been well assistend; I have nothing to complain about it. Here, the boys from the health unit come, they deliver condoms, deliver contraceptives, it's very good. They set the tests for us to do; and when we go, we are well received (Cicinha). When I feel a pain, anything, I go quickly and pay. Paying, they provide care more rapidly (Leonora).

\section{Discussion}

The study had as limitation the collection in only one establishment, which occurred as a result of the denial of the other establishments approached.

The early onset of sexual activity, pregnancy, and frequent use of alcoholic beverages are commonly observed among sex workers ${ }^{(15)}$. The age profile directly influences the exercise of prostitution, resulting in a greater number of clients as a function of youth. The start of prostitution has socioeconomic conditions as one of the causes, which are also responsible for the persistence of the practice. However, not always that health and life conditions, or financial conditions improve make these women to leave prostitution ${ }^{(1)}$.

Lack of employment opportunities, migration to large urban centers, having to provide to children in the condition of single mothers, lack of affection, and traumas in childhood and adolescence are among the main socioeconomic and psychological factors that determine the insertion in prostitution. Despite of this, it is a work that exists and provides the sustenance of many women and their families; however, because it is a work considered dirty and profane, it is marked by prejudice ${ }^{(16)}$.

It was noted that sex workers lived under unhealthy conditions, exposed to risk and increased vulnerabilities. They have not developed mechanisms to break the cycle of exploitation of the female body, which produces an expropriation of their work. 
Despite the prevailing prejudice, the main concern is with the acceptance of the family ${ }^{(17)}$. In another study, the sex workers interviewed reported they are rejected by neighbors, family and friends because of the work they $\mathrm{do}^{(1)}$. However, apart from the morality of prostitution, the biggest problem is the stigma attached to their occupation and marginalization, which eventually creates barriers to access to health and other social needs, especially its negative effect on working conditions, personal life, and sexual health $^{(18)}$. On the other hand, the family represents the major motivation to continue, mainly to give to the children what they need and to offer them a better financial condition ${ }^{(3)}$. Sex workers understood that their labor activity was marked by social boundaries, and this made them worry that their children would suffer when they learned about their prostitution.

Prostitution presents vulnerabilities arising from the very nature of the activity and the conditions under which it is exercised. Women are constantly exposed to STIs, submission, and abusive use of alcohol and illicit drugs ${ }^{(4)}$. Even when exposed to risk factors, they end up seeking care only when other measures such as self-medication do not meet their needs ${ }^{(3)}$.

The difficulty of these professionals in perceiving themselves as women who need comprehensive care, and not only care focused on reproductive and sexual problems, stands out ${ }^{(16)}$. In this population, health practices are centered on medical consultations (as soon as they detect signs or symptoms of pathologies), routine exams, condom use, and STI prevention measures $^{(3,17)}$.

Therefore, health care becomes indispensable. A survey on self-care with sex workers showed that, apart from seeking emergency care, they did not mention leisure, sports, culture, environment and safety as a means of caring for health ${ }^{(16)}$. Thus, sex workers are still included in health actions limited to measures for prevention of STIs and contraception, and this position is decisive in endorsing the social marginalization of this group ${ }^{(8)}$. In this scope, there is a shortage of health promotion actions aimed at this vulnerable population group, because health care is fundamentally focused on disease prevention.

The exercise of prostitution itself can not be taken as a cause of greater vulnerability to the acquisition of diseases, be them sexual or not. It is necessary to improve and expand services that are close to the daily routine of sex workers and the strategies they already use to receive health care ${ }^{(11)}$. When these women have health needs and seek care, they prefer to pay to ensure they will receive care in a timely manner, due to the delay in having consultations in the public network.

In this sense, the search for private services is due to the ease of access and time to perform exams ${ }^{(3)}$. The existence of health services in the community does not necessarily translate into their use, because sex workers do not feel comfortable looking for health professionals living in the community ${ }^{(6)}$.

Thus, in this scenario, sex workers opt for private services; they seek public services only when there are financial restrictions. The frequency of consultations is greater among those who say they go whenever they need, and lower among those who only go in cases of emergency ${ }^{(6)}$. Emergency services are used because of the difficulty in getting care. However, this demand generates discontinuity in care ${ }^{(5)}$.

Access to health services is influenced by the prevalence of institutional barriers, which include long waiting times and limited working hours ${ }^{(19)}$. Given the dynamics of their work, it is inconvenient to wait during a whole day, and often return home without having received the desired service ${ }^{(6)}$.

Another institutional barrier is related to the migratory and temporary aspect typical of sex work, which limits access to community health services, because such services require confirmation of an address of residence ${ }^{(4)}$. These barriers generate discontinuity of care in the points of the care network and can potentially increase the inequities of a health system that must be universal, equitable and comprehensive.

Building a fairer society and quality health requires the deconstruction of stereotypes and the 
consolidation of effective channels where it is possible to identify the demands and needs of sex workers, and more importantly, consider the premise that it is not possible to discuss health without taking into account human rights, gender relations, sexual division of labor, and the way society perceives the occupation exercised by these women ${ }^{(2)}$.

In order to enhance access to services, improvements should focus on user respect, confidentiality, and adjustments of policies and approaches that may hamper access to services, including ways to meet the needs of these women taking into account their transitory life style ${ }^{(6)}$. It is also necessary to include programmatic actions that foster knowledge about the care and functioning of health services, as well as to inform these women about their rights and duties ${ }^{(17)}$.

In this sense, nurses stand out because they are the protagonists of the actions of disease prevention and health promotion carried out in primary care, actions that must transpose taboos, prejudices and cultural values ${ }^{(8)}$. Thus, no health promotion action can proceed without the participation of the educational component, which should give people the opportunity to become multipliers of this process ${ }^{(1,17)}$.

In view of the above, it is necessary to strengthen the training of nurses since their academic training, so as to enable them to provide care that meets the demands of these women, with the development of guidance and counseling practices on STIs, to prevent these diseases, through an active search for follow-up in gynecological consultations and health promotion actions. It is important to emphasize that these actions must be carried out intersectorally, including the participation of associations of sex workers ${ }^{(1)}$.

\section{Conclusion}

The daily routine of women in situations of prostitution is marked by work in different places, which results in constant trips to other cities, absence of labor rights, poor hygiene conditions, and the una- vailability of inputs inherent to work. Thus, it is understood that the routine of work in this context places women in situations of clinical and social fragility, exposing them to vulnerabilities in health.

Regarding access to health services, it was perceived that care is hampered by institutional and social barriers. It is, therefore, necessary to create strategies aimed at this population, such as flexible days and times for assistance, and care tailored to their availability. Furthermore, health promotion programs for women are necessary to allow the provision of decent and equitable care.

\section{Acknowledgements}

To the Conselho Nacional de Desenvolvimento Científico e Tecnológico by the Scientific Initiation scholarship provided, Process no $127785 / 2014-0$.

\section{Collaborations}

Brito NS and Quirino GS contributed in the conception and design, analysis and interpretation of the data, writing of the article and final approval of the version to be published. Belém JM, Oliveira TM and Albuquerque GA contributed to the writing of the manuscript, relevant critical revision of the intellectual content, and final approval of the version to be published.

\section{References}

1. Penha JC, Aquino CBQ Neri EAR, Reis TGO, Aquino PS, Pinheiro AKB. Risk factors for sexually transmitted diseases among sex workers in the interior of Piauí, Brazil. Rev Gaúcha Enferm. 2015; 36(2):63-9. doi: http://dx.doi.org/10.1590/19831447.2015.02.52089

2. Sousa FR. Educação Popular em Saúde e participação de prostitutas: contribuições para a gestão participativa do SUS. Interface (Botucatu). 2014; 18(Suppl 2):1568-8. doi: http://dx.doi. org/10.1590/1807-57622013.0406 
3. Szwarcwald CL, Almeida WS, Damacena GN, SouzaJúnior PRB, Ferreira-Júnior OC, Guimarães MDC. Changes in attitudes, risky practices, and HIV and syphilis prevalence among female sex workers in Brazil from 2009 to 2016. Medicine. 2017; 97(1 suppl):46-53. doi: http://doi.org/10.1097/ MD.0000000000009227

4. Wahed T, Alam A, Sultana S, Rahman M, Alam $\mathrm{N}$, Martens $\mathrm{M}$, et al. Barriers to sexual and reproductive healthcare services as experienced by female sex workers and service providers in Dhaka city, Bangladesh. PLoS One. 2017; 12(7):e0182249. doi: https://doi.org/10.1371/ journal.pone.0182249

5. Love R. Street level prostitution: a systematic literature review. Issues Ment Health Nurs. 2015; 36(8):568-77. doi: https://doi.org/10.3109/016 12840.2015 .1020462

6. Wanyenze R, Musinguzi G, Kiguli J, Nuwaha F, Mujisha G, Musinguzi J, et al. When they know that you are a sex worker, you will be the last person to be treated": Perceptions and experiences of female sex workers in accessing HIV services in Uganda. BMC Int Health Hum Rights. 2017; 17(1). doi: http://doi.org/10.1186/s12914-017-0119-1

7. Pan American Health Organization. Strategy for universal access to health and universal health coverage. Proceedings of the 53rd Directing Council (CD53/5, Rev. 2) [Internet]. 2014 [cited out 31, 2018]. Available from: https://www.paho. org/hq/dmdocuments/2014/CD53-5-e.pdf

8. Villa EA, Cândido MCRM, Siste LF. A assistência à saúde das profissionais do sexo no Brasil: uma revisão integrativa. J Nurs Health. 2016; 1(1):92102. doi: http://dx.doi.org/10.15210/jonah. v6i1.6054

9. Mastrocola EL, Taylor AK, Chew-Graham C. Access to healthcare for long-term conditions in women involved in street-based prostitution: a qualitative study. BMC Fam Pract. 2015; 16:118. doi: https:// doi.org/10.1186/s12875-015-0331-9

10. Draper J. Ethnography: principles, practice and potential. Nurs Stand. 2015; 29(36):36-41. doi: http://dx.doi.org/10.7748/ns.29.36.36.e8937
11. Marques MC, Gomes LSV. As profissionais do sexo e a justiça do trabalho. Brasiliana J Braz Stud. 2013; 2(2):113-40. doi: https://doi.org/10.25160/ $\mathrm{v} 2 . \mathrm{i} 2 / \mathrm{d} 5$

12. Vinuto J. A amostragem em bola de neve na pesquisa qualitativa: um debate em aberto. Temáticas [Internet]. 2014 [citado 2018 set 13]; 22(44):203-20. Disponível em https://www.ifch. unicamp.br/ojs/index.php/tematicas/article/ view/2144/1637

13. Minayo MCS. Manuais acadêmicos: pesquisa social. Petrópolis: Vozes; 2016.

14. Boubonnais A. L'ethnographie pour la recherche infirmière, une méthode judicieuse pour mieux comprendre les comportements humains dans leur contexte. Rech Soins Infirm. 2015; 1(120):2334. doi: https://doi.org/ 10.3917/rsi.120.0023

15. Prakash R, Manthri S, Tayyaba S, Joy A, Raj SS, Singh D, et al. Effect of physical violence on sexually transmitted infections and treatment seeking behaviour among female sex workers in Thane District, Maharashtra, India. PLoS One. 2016; 11(3):e0150347. https://doi.org/10.1371/ journal.pone. 0150347

16. Marques DMD, Costa DR. A saúde e a "vida" das profissionais do sexo. Investig Qual Saúde [Internet]. 2015 [citado $2018 \mathrm{dez}$ 13]; 2:198-202. Disponível em: https://proceedings.ciaiq.org/ index.php/CIAIQ/article/view/522/517

17. Paiva LL, Araujo JL, Nascimento EGC, Alchieri JC. Vivência das profissionais do sexo. Saúde Debate. 2013; 37(8):467-76. doi: http://dx.doi. org/10.1590/S0103-11042013000300010

18. Benoit C, Jansson SM, Smith M, Flagg J. Prostitution stigma and its effect on the working conditions, personal lives, and health of sex workers. J Sex Res. 2018; 55(4-5):457-71. doi: http://doi.org/1 $0.1080 / 00224499.2017 .1393652$

19. Oliveira GS, Nogueira JA, Costa GPO, Silva FV, Almeida SA. Access by lesbians, gays, bisexuals and transvestites/transsexuals to the Basic Family Health Units. Rev Rene. 2018; 19:e3295. doi:http://dx.doi.org/10.15253/21756783.2018193295 